\title{
VetBact - culturing bacteriological knowledge for veterinarians
}

\begin{abstract}
In 2004, Karl-Erik Johansson, then professor of veterinary bacteriology at the veterinary school at Uppsala in Sweden, was asked by his students for a list of the most important bacteria and the diseases that they cause. So began the development of VetBact, an online database giving details of the bacterial species with most relevance to veterinary medicine. The non-commercial database, www.vetbact.org, has since grown and can now be accessed by veterinarians and others worldwide.
\end{abstract}

I was appointed professor in veterinary bacteriology in 2004 and spent half my time at the Department of Biomedical Sciences and Veterinary Public Health (BVF) in the veterinary faculty at the Swedish University of Agricultural Sciences (SLU) and the other half at the Department of Bacteriology of the National Veterinary Institute (SVA). When I started to give lectures in bacteriology for veterinary students in their second year, they told me that they found bacteriology very complicated with all the bacterial names and corresponding diseases. They asked for a list of the most important bacteria and the diseases they cause.

When I met those students again in spring 2005, I had prepared a list for them, consisting of two A4 pages with important bacteria and their characteristics. It was intended to complement the lectures and the course textbook (Veterinary Microbiology and Microbial Disease by Quinn and others). The list was much appreciated.

After the bacteriology course, I began to think about updating the list for the next year's course. I realised that a website containing the information would be much more flexible and useful for both the students and also for myself. Therefore, in collaboration with Staffan Tamm at the SVA, who has great experience of database-driven websites, I began to develop a database with information
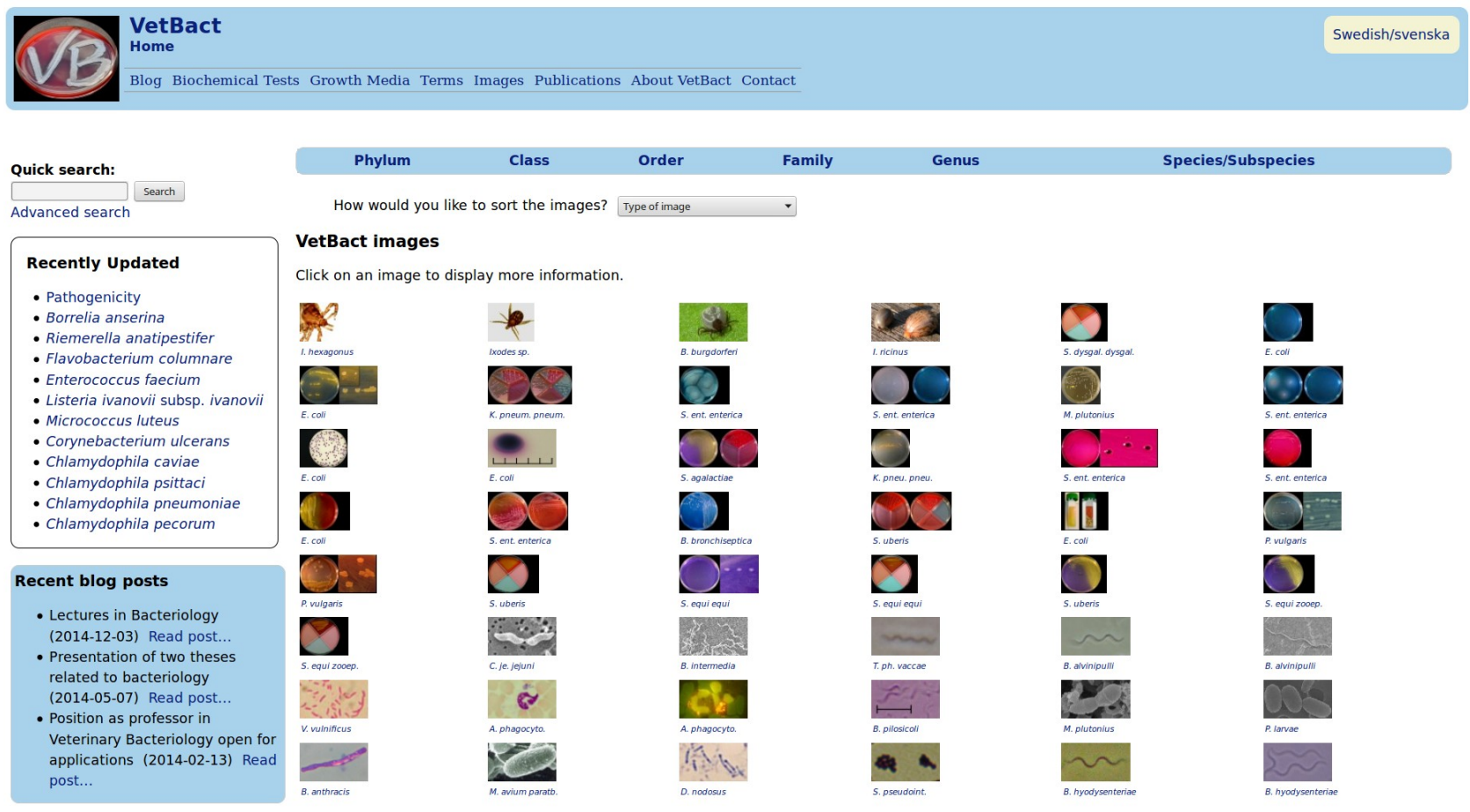

The VetBact database (www.vetbact.org) contains information on more than 200 species of bacteria of veterinary importance, including a range of images. 
about bacteria that are of importance in veterinary medicine. The project was named VetBakt and the aim was to create a new tool for Swedish veterinary students and their teachers for use during the bacteriology-related courses of the veterinary programme.

The first version of VetBakt became available on the internet in 2006, as a part of the SVA website. Many revisions and updates were introduced over the following year before a new version was launched as a separate website. Many foreign guests who visited the site asked for an English version and so we began to translate VetBakt into English. By 2010 VetBakt was bilingual and we changed the spelling to VetBact. We also moved it to a hosting service site with improved capacity.

\begin{tabular}{|c|c|c|c|c|c|c|c|}
\hline Phylum & Class & \multicolumn{2}{|l|}{ Order } & amily & & Genus & Species/Subspecies \\
\hline Species/Subspecies: & \multicolumn{7}{|c|}{ Escherichia coli } \\
\hline Etymology: & \multicolumn{7}{|c|}{$\begin{array}{l}\text { Genus name: named after the German pediatrician Theodor Escherich, who first isolated the type species of the genus. } \\
\text { Species epithet: from the large intestine (colon). }\end{array}$} \\
\hline Significance: & \multicolumn{7}{|c|}{ | [Very important] | | } \\
\hline \multirow[t]{2}{*}{ Taxonomy: } & Phylum & \multicolumn{2}{|l|}{ Class } & \multicolumn{2}{|l|}{ Order } & Family & Genus \\
\hline & Proteobacteria & \multicolumn{2}{|c|}{ Gammaproteobacteria } & \multicolumn{2}{|c|}{ Enterobacteriales } & Enterobacteriaceae & Escherichia \\
\hline Type Strain: & \multicolumn{7}{|c|}{ ATCC $11775=$ CCUG $29300=$ NCTC 9001.} \\
\hline Macromorphology (sm & \multicolumn{7}{|c|}{$\begin{array}{l}\text { Medium sized ( } 3-6 \mathrm{~mm} \text { in diameter), opaque, sticky and greyish white colonies. Some strains give a narrow clear hemolysis zone } \\
\text { on blood agar. Characteristic odor. }\end{array}$} \\
\hline Micromorphology: & \multicolumn{7}{|c|}{ Short motile rods $(0.5 \times 1-3 \mu \mathrm{m})$ with peritrichous flagella. } \\
\hline Gram +/Gram -: & \multicolumn{7}{|l|}{ G- } \\
\hline $\begin{array}{l}\text { Metabolism: } \\
\text { Catalase/Oxidase: } \\
\text { Other Enzymes: } \\
\text { Biochemical Tests: }\end{array}$ & \multicolumn{7}{|c|}{$\begin{array}{l}\text { DNase -, } \beta \text {-glucoronidase }+(\mathrm{cf.} \text { Klebsiella spp. }) \text {, esculinase } \mathrm{V} \text {, ornithine decarboxylase } \mathrm{V} \text {, tryptophanase }+(=\text { indol }+) \text {, urease }- \text {. } \\
\text { Citrate }- \text {, hydrogen sulphide }\left(\mathrm{H}_{2} \mathrm{~S}\right)-\text {, methyl red }+ \text {, Voges-Proskauer }-.\end{array}$} \\
\hline \multirow{7}{*}{$\begin{array}{l}\text { Fermentation of } \\
\text { carbohydrates: }\end{array}$} & D-glucose & lactose & maltose & L-rhamnose & sucros & ose & \\
\hline & + & + & $+\quad(1$ & $(+)$ & v & & \\
\hline & L-arabinose & cellobiose & D-mannitol & salicin & trehal & lose & \\
\hline & + & - & + & $\mathrm{v}$ & + & & \\
\hline & glycerol & inulin & raffinose & D-sorbitol & starch & & \\
\hline & $(+)$ & $?$ & v & + & $?$ & & \\
\hline & \multicolumn{7}{|c|}{$\begin{array}{l}\text { Both gas and acid are formed by those carbohydrates that are fermentable. There are biochemically inactive strains, which do } \\
\text { not ferment some of the above carbohydrates. }\end{array}$} \\
\hline Microbiological tests: & \multicolumn{7}{|c|}{ Motility test is sometimes performed to confirm suspected findings of $E$. coli. } \\
\hline \multicolumn{8}{|c|}{ 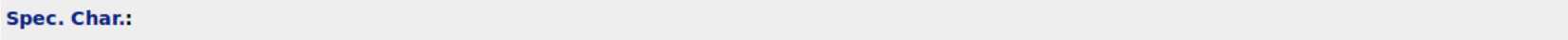 } \\
\hline Special Media: & \multicolumn{7}{|c|}{$\begin{array}{l}\text { BG medium is used to distinguish between E. coli and Salmonella spp. Chromogenic E. coli/coliform selective agar is used for } \\
\text { enumeration of coliform bacteria. Doppsticka (t.ex. UriCult används i samband med urinvägsinfektioner). Dip s }\end{array}$} \\
\hline Hosts: & \multicolumn{7}{|c|}{ Many different animal species (including humans). } \\
\hline Disease (Swedish): & \multicolumn{7}{|c|}{$\begin{array}{l}\text { Olika patotyper ger olika sjukdomar (enteriska, septikemiska m.fl.). Ödemsjuka hos gris (patotyp VTEC), avvänjningsdiarré hos } \\
\text { gris (patotyp ETEC) och hemorragisk kolit hos människa (patotyp EHEC). (Matförgiftning) }\end{array}$} \\
\hline Disease (English): & \multicolumn{7}{|c|}{$\begin{array}{l}\text { Different pathotypes cause various diseases (enteric, septicaemic and others). Edema disease in pigs (pathotype VTEC), } \\
\text { weaning diarrhea in pigs (pathotype ETEC) and hemorrhagic colitis in humans (pathotype EHEC). (Food Poisoning) }\end{array}$} \\
\hline
\end{tabular}

An example of the type of information available on VetBact about different bacterial species - in this case Escherichia coli.

Since then, we have added three new modules: VetBactBlog, VetBactQuiz and VetBactLab. The purpose of VetBactBlog is to give students the chance to discuss relevant issues in veterinary bacteriology and for us to inform users about updates and improvements to VetBact, as well as interesting events in veterinary bacteriology. VetBactQuiz allows students to check their knowledge and receive direct feedback.

VetBactLab is a module for virtual experiments in laboratory diagnostics. Six different cases were initially available to the students and they were challenged to establish an accurate laboratory diag- 
nosis as quickly and cheaply as possible. Each diagnostic tool in VetBactLab has a time and a cost implication. More cases were subsequently added in 2012 and six virtual experiments in food bacteriology were introduced in 2013.

A basic design idea is that the database in VetBact can be used in several ways and for different purposes. This means, for instance, that the data that have been entered into the database can be displayed not only for visitors to a specific web page, but can also simultaneously serve as a basis for questions and answers to the quizzes (VetBactQuiz), and be used as reference material in the virtual cases/experiments (VetBactLab). During the spring of 2011, I retired, but I continue to work with the VetBact project for one to two days each week as professor emeritus.

\section{Current status}

Today, VetBact contains information about 216 bacterial species belonging to 83 genera. It contains more than 100 references to scientific articles, theses and other websites. The database also contains a list of terms relating to bacteriology, explaining the meaning of words such as 'siderophore' and 'biofilm'.

There are about 370 pictures of colonies, Gram stainings, electron micrographs, phylogenetic trees, and so on. All these images can be downloaded and used for non-commercial purposes, as

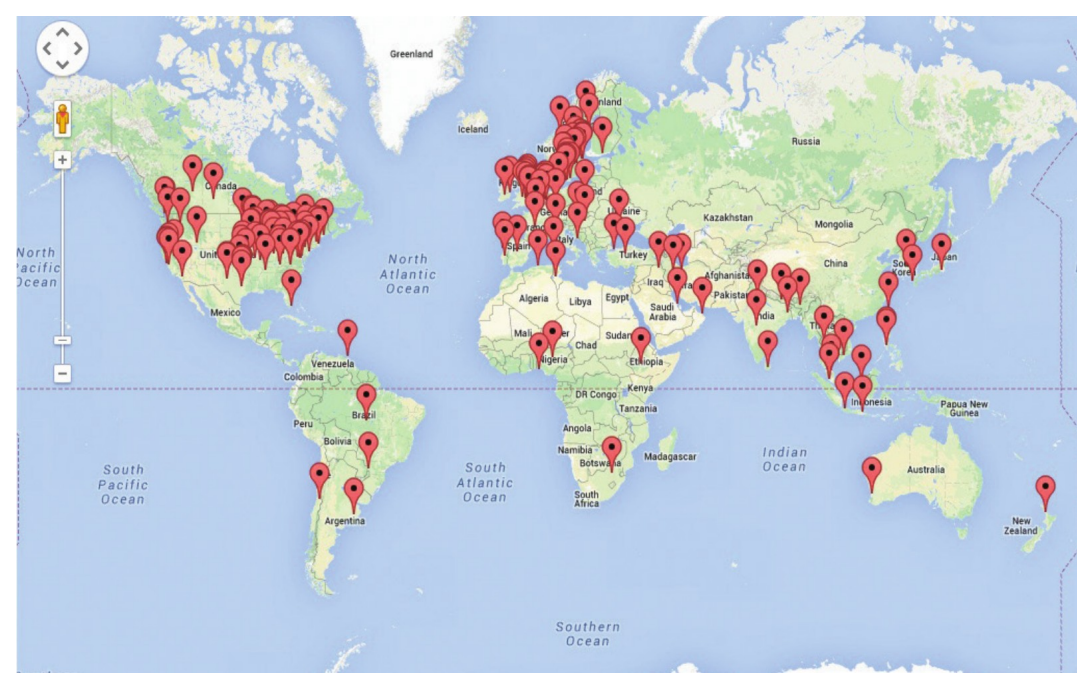

Over a two-day period (December 13 to 15, 2013) visitors representing 46 different countries accessed VetBact. Most came from the USA, Sweden, Malaysia and UK. (Information retrieved from StatCounter.org). they are licensed under a Creative Commons Attribution- Noncommercial-No Derivative Works 2.5 License.

While access to the VetBactLab module requires users to log in (see blue box), there are six different quizzes available to VetBact visitors without using a password. These cover Gram staining, haemolysis, motility, spore forming, disease and images.

\section{Information sources}

The data in VetBact have been collected from lectures given to veterinary students, from discussions with bacteriologists at SVA and BVF in Sweden, from textbooks in bacteriology, from Bergey's Manual of Systematic Bacteriology ( $2^{\text {nd }}$ edn), scientific articles and theses, as well as from the internet. We are also in contact with veterinary bacteriologists in Berne and in Guelph.

\section{Accessing the database}

Access to almost all of VetBact is freely available. The primary goal is that it should be a pedagogic tool for veterinary students and their teachers to use during bacteriology courses and during other courses related to bacteriology. However, it is also used by veterinary clinicians and could be useful to anyone working in the field of veterinary bacteriology.

Log in details are necessary for theVetBactLab module, but the VetBact team will be pleased to supply any veterinary student or teacher in veterinary bacteriology with a password. Contact details are available at www.vetbact.org. 
VetBactLab is based on the bacteriological methods commonly used in veterinary bacteriology in Sweden. Of course, in other countries, other methods may be preferred.

VetBact also indicates the degree of veterinary importance of the bacteria using colour coding. Importance was assessed after interviewing approximately 15 teachers at the veterinary faculty in Sweden and reflects the situation in Sweden.

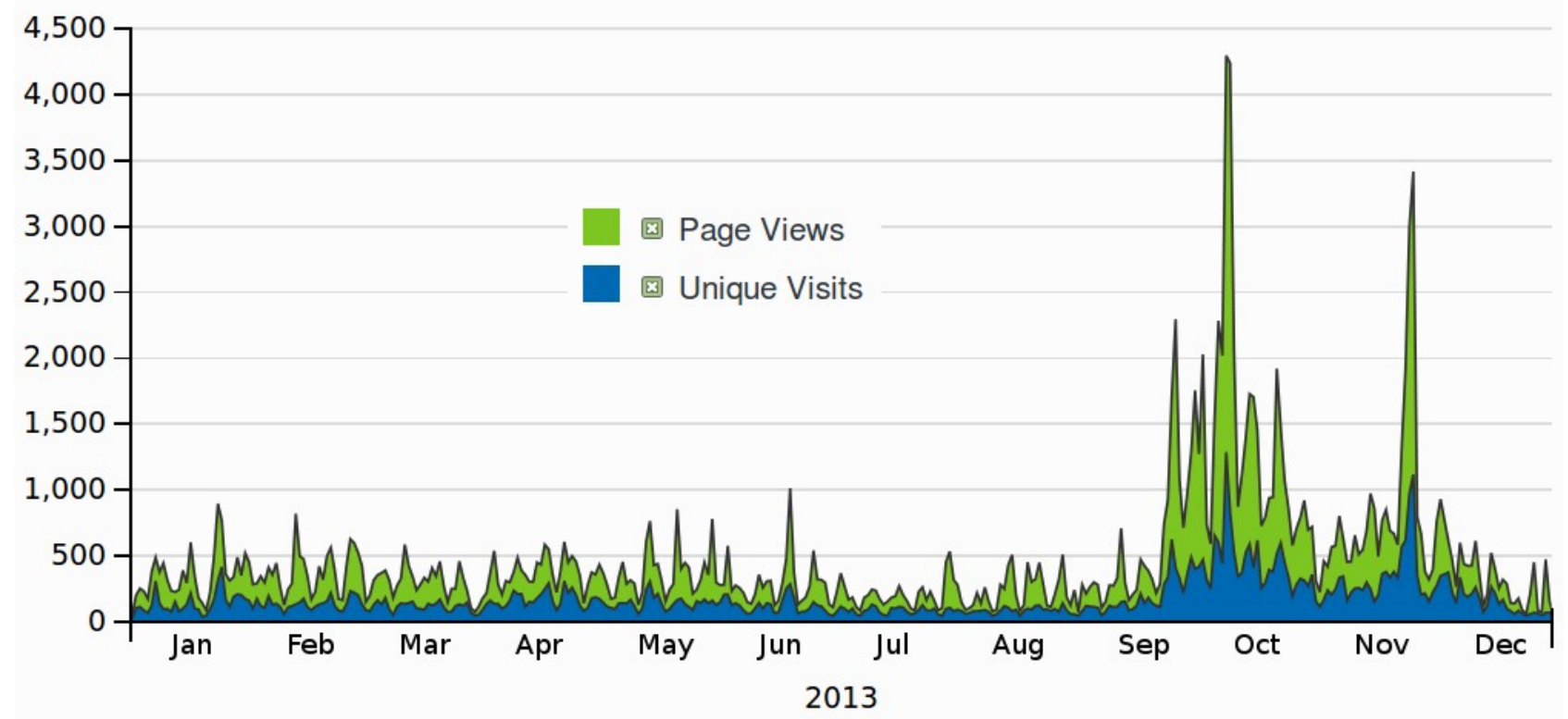

This graph shows the number of pages visited on VetBact between January 1, 2013 and December 31,2013 . The bacteriology course for veterinary students in Sweden starts on September 23 and on November 27 they sit the final examination in bacteriology. The peak on October 9 and 10 represents the days when the students perform a bacteriological analysis of a spiked 'clinical' sample. (Information retrieved from StatCounter).

\section{Funding}

General financial support for the development of VetBact has been obtained from SLU and from SVA. Direct financial support for the development of the database as a pedagogic project was also given by SLU. Further support has been received from the Thure F. and Karin Forsberg Foundation and from the Society for Veterinary Research in Sweden. There is no commercial involvement in the database.

\section{Striving for accuracy}

The data in VetBact have been verified by discussions during meetings of the reference group for VetBact. We also discuss different issues with the experts from whom data have been obtained. We cannot, of course, guarantee that everything in VetBact is completely correct and, from time to time, people do contact us about possible errors or ambiguities. We then try to revise the information to reflect the current knowledge as well as possible.

\section{Advantages of an online database}

There are several major advantages to having an online database as a supplement to textbooks, lectures and laboratory work.

- The information is readily available to all and free of charge. 
- Veterinary bacteriology is a dynamic topic and updates can be made continuously as new information becomes available or as a response to questions from users.

- Textbooks are expensive and quickly become outdated (often as soon as they are published) whereas a database can easily be updated.

- A textbook can never include as many images as a database. We have almost unlimited opportunities to put pictures on VetBact. This will become increasingly important in the future, when the number of experiments in bacteriology and food safety will be reduced because of financial constraints (at least in Sweden).

- The photographic material on VetBact may be used freely for non-commercial purposes if the source is mentioned and this can be used by students and researchers.

- The information contained in a database can be used to construct a virtual laboratory.

\section{Future developments}

During 2014, we plan to add three or four more virtual cases to VetBactLab. We will also add further entries to the list of bacteriological terms, add new images and replace some old images of unsatisfactory quality. The information relating to 'Disease', 'Clinical picture' and 'Virulence factors' on the information pages for the bacteria will be further extended.

Karl-Erik Johansson, Professor Emeritus in veterinary bacteriology, Department of Biomedical Sciences and Veterinary Public Health, Swedish University of Agricultural Sciences, Uppsala, Sweden e-mail: karl-erik.johansson@slu.se

\section{Continuing the project}

In 2011, a reference group was formed to ensure the continuation of the VetBact project after Professor Johansson fully retires. Professor Johansson currently coordinates the group, which consists of:

- Anna Bergfeldt, a veterinarian at BVF, SLU

- Lise-Lotte Fernström, a biomedical laboratory scientist at BVF, SLU

- Ingrid Hansson, a veterinarian at SVA

- Désirée Jansson, a veterinarian at SVA

- Susanna Sternberg Lewerin, a veterinarian at BVF, SLU

- Staffan Tamm, of SVA

- Gunilla Trowald-Wigh, a veterinarian at BVF, SLU 